\title{
ADSORPTION OF FUNGICIDES IN CHILEAN SOILS INCUBATED WITH BIOSOLIDS
}

\author{
SYLVIA V. COPAJA, HÉCTOR R. BRAVO AND PAOLA MUÑOZ \\ Departamento de Quimica, Facultad de Ciencias Universidad de Chile \\ Las Palmeras 3425, Ñuñoa.
}

(Received: May 13, 2011 - Accepted: January 20, 2012)

\begin{abstract}
The efficiency of the adsorption process of the fungicides Captan and Thiram was studied in four Chilean soils from the VI [O'Higgins, (HGS)], VII [Talcarehue, (THL)], VIII [Diguillin, (DIG)] and Metropolitan [Maipo, (MAO)] regions of Chile. Changes in the efficiency of adsorption when the natural soils were incubated with biosolids were analyzed.

The values of parameters $\mathrm{Kf}$ and $\mathrm{n}$ from the Freundlich equation indicated an increase in the adsorption of fungicides incubated with biosolids ( $1 \%$ and $10 \%)$ with respect to natural soil. A high Kf value (12.1) for DIG-Thiram and a lower Kf value (4.3) for MAO-Captan interaction were observed for natural soils, while in soils incubated with biosolids (10\%) the greatest value was (20.3) for DIG-Thiram and the lowest Kf value (10.2) for MAO-Captan. In general the high Kf values for Captan and Thiram were correlated with organic carbon content in the natural and incubated soils, except for the interaction THL-Thiram, in which inorganic compounds of soils (clay) were dominant.

The distribution constant between solid-liquid phases $(\mathrm{Kd})$ increased in soils incubated with biosolids; the magnitude of this constant was more significant with Thiram. The same behavior was observed for the constant related to organic carbon constants (Koc).

The results of this work confirm that amending soils with biosolids is beneficial for immobilizing fungicides and helps prevent the percolation of Captan and Thiram through the soil profile and into groundwater
\end{abstract}

Key words: soil, fungicide, biosolids, HPLC, Captan, Thiram

\section{INTRODUCTION}

One way to dispose of sewage sludge generated in wastewater treatment plants (WTP) is to apply it to agricultural soils, because these residues are a potential source of organic matter and nutrients for agriculture. In addition, their application to agricultural soils would solve an immediate and future problem of sewage sludge build-up resulting from the increase, in the last decade, in the number of WTP in Chile. Sludge disposal in degraded and eroded soils seems a good alternative for Chile, considering that a great part of the agricultural land shows erosion ranging from slight to serious. Even though there is vast foreign experience on the subject, the role of Chile as producer of a wide variety of agricultural export products makes it necessary to carry out preliminary studies with local soils.

Application as a complement to soil fertilization is currently the most common method of sewage sludge disposal. ${ }^{1-3}$ Sewage sludge can be recycled as a source of nutrients for plant growth and as a conditioner to improve physical and microbiological soil properties ${ }^{4}$. However, a major obstacle for recycling is that this residue also contains various contaminants ${ }^{5}$. Metals occurring as trace elements are of special concern because they may have toxic effects in the biota and accumulate in trophic webs. ${ }^{6,7}$. Mantovi et al. ${ }^{8}$ found that the application of sewage sludge brought about remarkable benefits to soil fertility but was associated with a possible negative effect on water quality due to increased $\mathrm{P}$ availability and on soil ecology due to $\mathrm{Zn}$ accumulation

Treated sewage sludge meeting regulations for pathogens is termed biosolids 9 .

The effect of applying of biosolids to land and the interaction with other chemical pollutants is not well known. Recently an increasing interest has been focused on the effects of these organic amendments on pesticide behavior in soils ${ }^{10}$; it has been demonstrated that organic amendments significantly change pesticide adsorption behavior into the soil ${ }^{11-18}$.

In general pesticides in the environment are ruled by the transformation process, which can include pesticide molecule breakdown by chemical, photochemical or biological degradation, or by a transfer process, such as adsorption/desorption, runoff, volatilization and leaching. Among transfer processes adsorption is a key process that largely controls the behavior of pesticides in soil, determining their distribution between the soil and the water system.

Captan and Thiram are two fungicides widely used in Chile; Captan is a compound of hydrophobic nature, while Thiram is hydrophilic ${ }^{19,20}$ (Table 1). The hydrophobic-hydrophilic equilibrium may be essential for dynamic equilibrium in soils. In this study we examine behavior related to the adsorption process of the fungicides Captan and Thiram in four Chilean soils incubated with biosolids ( $1 \%$ or $10 \%)$, from WTP "El Trebal"

\section{EXPERIMENTAL}

\subsection{Soil Samples}

Four Chilean soils ( 0 - $20 \mathrm{~cm}$ ), DIGUILLIN (DIG) (Region VIII), MAIPO (MAO) (MP Region), O'HIGGINS (HGS) (Region VI) and TALCAREHUE (THL) (Region VII) were selected. The soils were air-dried and sieved $(<2$ $\mathrm{mm})$.

Particle size distribution (texture) was determined by the pipette method 21. Organic carbon (OC) was determined by the Walkey and Black method 22. The $\mathrm{pH}$ and electrical conductivity (EC) for soil, sludge and sludge-soil combinations were determined in solid-water suspension $1: 2.5 \mathrm{w} / \mathrm{v}^{23}$.

\subsection{Biosolids}

Samples of biosolids from the WTP named El Trebal were first air dried and sieved $(<2 \mathrm{~mm})$; $\mathrm{pH}, \mathrm{EC}$ and $\mathrm{OC}$ were determined as for soil samples

\subsection{Chemicals}

Captan and Thiram standards were commerciality available products (Sigma Chemical Company). The commercial formulation was obtained from ANASAC; Captan 3.04\% and Thiram 24\%. Their chemical structures and some of their characteristics are shown in Figure 1 and Table 1, respectively.<smiles>O=C1C2CC=CCC2C(=O)N1SC(Cl)(Cl)Cl</smiles>

CAPTAN: $\mathrm{C}_{9} \mathrm{H}_{8} \mathrm{Cl}_{3} \mathrm{NO}_{2} \mathrm{~S}$ $\mathrm{N}$-(tricloromethylthio) ciclohex-4-ene-1,2dicarboxamide
Fig. 1. Chemical structure of: Captan and Thiram

Table 1. Physical characteristics of fungicides studied (physical constants at $25^{\circ} \mathrm{C}$ )

\begin{tabular}{|c|c|c|c|}
\hline Common name & $\log$ Kow & $\begin{array}{c}\text { Water solubility } \\
\left(\mathbf{m g ~ L}^{-1}\right)\end{array}$ & $\begin{array}{c}\text { Vapor } \\
\text { preassure } \\
(\mathbf{m m} \mathbf{H g})\end{array}$ \\
\hline Captan & 2.78 & 3.3 & $9 \times 10^{-8}$ \\
\hline Thiram & 1.73 & 40 & $1.73 \times 10^{-5}$ \\
\hline
\end{tabular}




\subsection{Incubation of soil with biosolids}

Incubation of soil with biosolids was conducted for a period of $30 \mathrm{~d}$. For this purpose, soils were mixed with doses of biosolids equivalent to $1 \%$ and $10 \%$ of to the total dry mass used. Incubation with natural soil ( $0 \%$ biosolids) was used as a control.

Incubation was carried out at room temperature in 1 liter plastic bottles with a total mass of $1 \mathrm{~kg}$ of soil incubated with biosolids. Incubated soils were irrigated with de-ionized water (MilliQ-grade) and periodically removed.

2.5 Adsorption study of fungicides in natural soils and soils incubated with biosolid.

$1 \mathrm{~g}$ of soil samples (natural and incubated), were treated in $250 \mathrm{~mL}$ plastic bottles with $10 \mathrm{~mL}$ solution of Captan or Thiram in a concentration range from 0 to $1000 \mathrm{mg} \mathrm{L}^{-1}$. Stock solutions of both fungicides were prepared in acetonitrile (HPLC grade) and a $0.01 \mathrm{M}$ solution of $\mathrm{CaCl}_{2}$ (Fluka p.a.) was used to complete the total volume $(10 \mathrm{~mL})$. The suspensions were agitated at $23 \pm 2^{0}$ $\mathrm{C}$ in a batch system for $24 \mathrm{~h}$, long enough to reach equilibrium. Subsequently, samples were centrifuged for 15 minutes at $4000 \mathrm{rpm}$, and supernatants were stored in cold for further analysis. Each adsorption experiment was performed in duplicate. Losses during the process were monitored by including two blank controls in each test: one plastic bottle that only had a chemical solution without any adsorbent and another with only the adsorbent and $\mathrm{CaCl}_{2}$ solution without chemical solution. The amount of each compound adsorbed in the soil phase, Cs $\left(\mathrm{mgkg}^{-1}\right)$ was obtained by subtracting from the amount of compound in the initial solution the amount measured the aqueous phase. Thus it was assumed that processes such as degradation, volatilization or photolysis were not significant during the $24 \mathrm{~h}$ period.

\subsection{Chemical analysis}

The concentration of both fungicides in equilibrium was determined using a liquid chromatograph (Waters 1525) high resolution (HPLC) method under the following conditions: Column Waters Symmetry $\mathrm{C}_{18}$, mobile phase: acetonitrile / water $80: 20$, flow rate: $1.0 \mathrm{~mL} / \mathrm{min}$ and injection volume: $20 \mu \mathrm{L}$. The detection of compounds was performed using a diode array detector (PDA Waters model 2996)) at wavelengths of $277 \mathrm{~nm}$ and $254 \mathrm{~nm}$ for Thiram and Captan, respectively. Retention times $\left(\mathrm{t}_{\mathrm{R}}\right)$ of Captan and Thiram standards were $2.35 \pm 0.04$ and $1.72 \pm 0.02 \mathrm{~min}$, respectively. These $t_{R}$ were compared with $t_{R}$ from a commercial formulation.

\section{RESULTS AND DISCUSSION}

\subsection{Physical and Chemical properties of soil and biosolid}

The textural characteristics of the four soils studied (Table 2) show that the clay content decreased in the order DIG $>$ THL $>$ MAO $>$ HGS. Table 3 shows the increase of $\mathrm{OC}$ of the natural soils when they were incubated with biosolid from WTP El Trebal, and also shows changes in $\mathrm{pH}$ and EC produced.

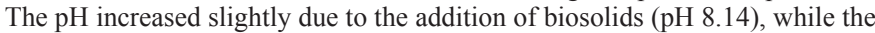
EC increased from three to four times with addition of biosolids, especially at $10 \%$, because the biosolids provided the soil with numerous chemical species (anions and cations) which contributed to increase the EC

Table 2. Textural characteristics of the soils used in the study

\begin{tabular}{|c|c|c|c|c|}
\hline Soils & Clay \% & Sand \% & Silt \% & $\begin{array}{c}\text { Soil Texture } \\
\text { (USDA) }\end{array}$ \\
\hline DIG & 12.17 & 68.55 & 19.27 & Sandy loam \\
\hline MAO & 5.47 & 76.76 & 17.78 & Sandy loam \\
\hline HGS & 3.01 & 60.83 & 36.16 & Sandy loam \\
\hline THL & 11.04 & 52.83 & 36.13 & Loam \\
\hline
\end{tabular}

\subsection{Adsorption of fungicides in soils and biosolids}

Figures 2 and 3 shows the data from adsorption isotherms and the points adjusted for each isotherm by the equation $\mathrm{Cs}=\mathrm{Kd}$. $\mathrm{x} \mathrm{Ce}$, where $\mathrm{Cs}$ is the concentration of pesticide in soil $\left(\mathrm{mg} \mathrm{g}^{-1}\right)$, Ce is the concentration in solution $\left(\mathrm{mg} \mathrm{L}^{-1}\right)$ and $\mathrm{Kd}$ is the distribution coefficient of each fungicide between water and soil. Adsorption isotherms of Captan and Thiram were obtained on natural soils and soils incubated with biosolids. In all cases, L-type curves according to the classification of Giles et al. $(1960)^{25}$ were observed. In these cases Kd calculated was the average between all the points of the curve (Table 4). This value is not constant and varies greatly depending on the soil properties studied. However there is a way to normalize the values of this coefficient, based on the content of organic matter, to obtain the adsorption constant applicable to all types of soil24. This pattern is represented as the organic carbon partition coefficient $\mathrm{Koc}=(\mathrm{Kd} / \% \mathrm{OC}) \times 100($ Table 4$)$.

Table 3. Characteristics of biosolids, natural soils $(0 \%)$ and soils incubated with biosolids (1 and 10\%).

\begin{tabular}{|c|c|c|c|}
\hline Samples & $\mathbf{p H}$ & $\begin{array}{c}\mathbf{E C} \\
\mathbf{d S} / \mathbf{m})\end{array}$ & $\begin{array}{c}\text { OC } \\
\mathbf{( \% )}\end{array}$ \\
\hline Biosolids & 8.14 & 1.41 & 15.26 \\
\hline DIG $-0 \%$ & 5.71 & 0.23 & 2.74 \\
\hline DIG $-1 \%$ & 5.82 & 0.36 & 2.84 \\
\hline DIG $-10 \%$ & 6.15 & 0.76 & 4.46 \\
\hline MAO $-0 \%$ & 7.32 & 0.29 & 1.09 \\
\hline MAO - $1 \%$ & 7.53 & 0.37 & 1.25 \\
\hline MAO $-10 \%$ & 7.84 & 0.95 & 2.71 \\
\hline HGS $-0 \%$ & 6.11 & 0.24 & 2.32 \\
\hline HGS $-1 \%$ & 6.25 & 0.34 & 2.49 \\
\hline HGS $-10 \%$ & 6.42 & 0.91 & 3.71 \\
\hline TLH $-0 \%$ & 5.82 & 0.23 & 1.21 \\
\hline TLH $-1 \%$ & 6.14 & 0.34 & 1.27 \\
\hline TLH $-10 \%$ & 6.45 & 0.87 & 2.72 \\
\hline
\end{tabular}

The adsorption curves of Captan fungicide in the four natural soils are shown in Figure 2. Captan adsorption was proportional to the OC content in soils, DIG $>$ HGS and THL $>$ MAO (Table 3 ). The adsorption curves of Thiram fungicide in four natural soils are shown in Figure 3. Thiram showed better affinity with DIG and THL soils and poorer affinity with HGS and MAO soils; this behavior is accordance with the contents of clay matter and OC in these soils (Table 2).

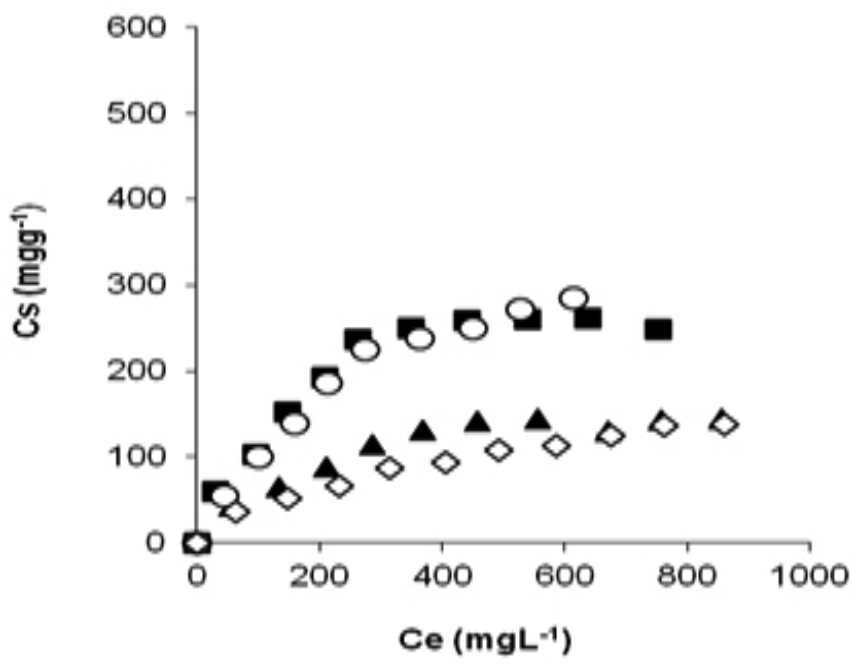

Fig. 2. Adsorption curves of Captan in natural soils (without incubation): m:DIG-Captan, $\boldsymbol{\Delta}$ THL-Captan, OHGS-Captan, $\diamond$ MAO-Captan

The effects of OC on the adsorption of Captan and Thiram were evaluated from comparative curves of adsorption for both fungicides in the natural soils DIG and THL and incubated with $1 \%$ and $10 \%$ biosolids. Figure 4 shows the adsorption curves of both fungicides. 


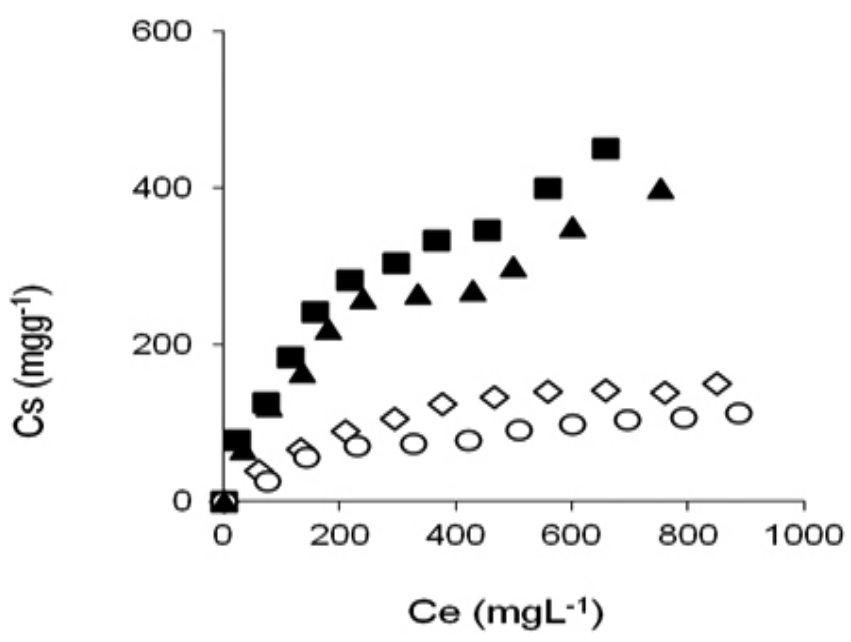

Fig. 3. Adsorption curves of Thiram in natural soils (without incubation): -:DIG-Thiram, $\boldsymbol{\Delta}$ THL-Thiram, OHGS-Thiram, $\diamond$ MAO-Thiram

Captan showed the highest adsorption in both soils incubated with $10 \%$ biosolids, indicating a high affinity with OC provided by the biosolids $(15.26 \%)$. The adsorption curves of Thiram in the soils were relatively similar and incubation with biosolids was not important in the adsorption process. Different affinity of OC may arise from the different hiydrophobicity, lipophilicity and solubility (Table 1) of Captan and Thiram.

\subsection{Freundlich isotherms}

A model for the adsorption of the fungicides by the soil was obtained from the Freundlich isotherm equation: $\ln \mathrm{Cs}=\ln \mathrm{Kf} \mathrm{Ce}+\mathrm{n}$, where $\mathrm{Kf}$ is the adsorption coefficient and $\mathrm{n}$ is related to the degree of adsorption. Table 4 shows the $\mathrm{Kf}$ and $\mathrm{n}$ values for Captan and Thiram fungicides; the $\mathrm{Kd}$ and Koc constants were included. Correlation coefficients were between 0.9914 for THL-Captan ( $1 \%$ biosolids) and 0.9996 for DIG.Captan (10\% biosolids).
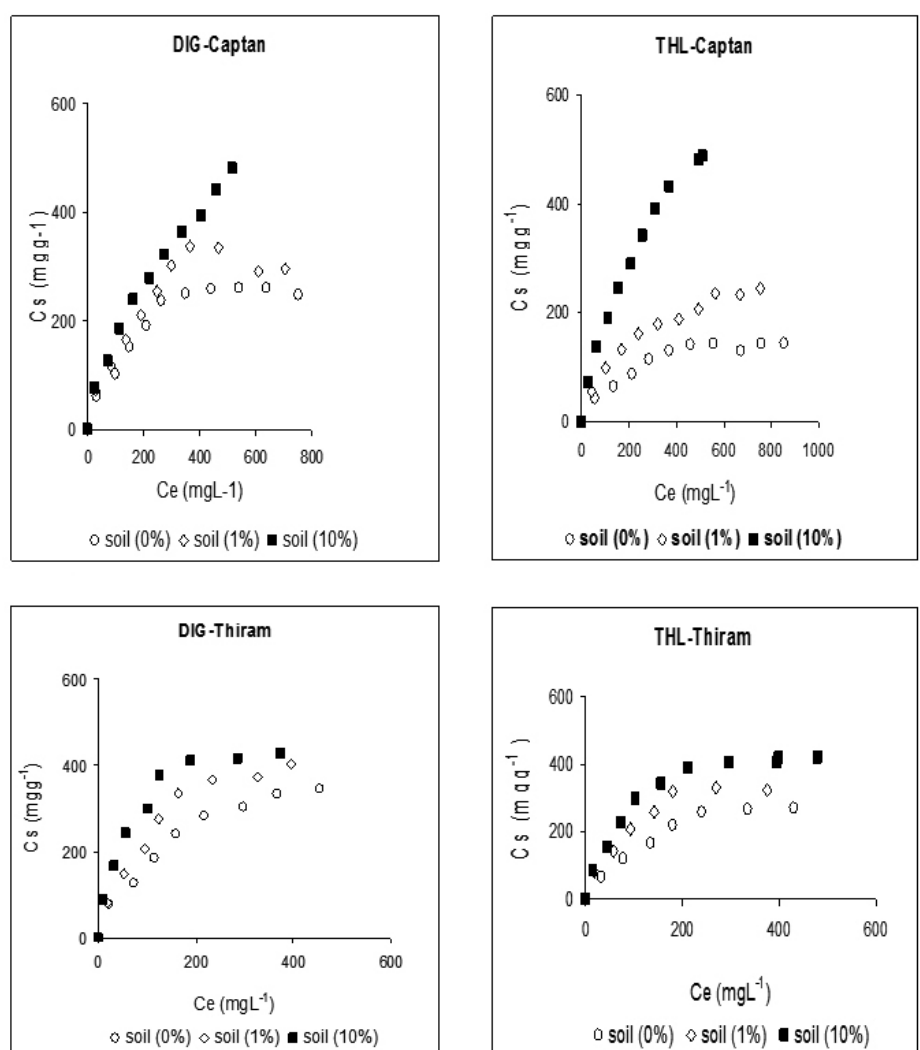

Fig. 4. Adsorption curves of Captan and Thiram in soils DIG and THL with $0 \%(\bigcirc), 1 \%(\diamond)$ and $10 \%(\square)$ biosolids.

Table 4. Freundlich parameters, distribution coefficients $(\mathrm{Kd})$ and organic carbon normalized distribution coefficients (Koc) for Captan and Thiram in natural soils and soils incubated with biosolids.

\begin{tabular}{|c|c|c|c|c|c|c|c|c|c|c|}
\hline \multirow[b]{2}{*}{ Soils } & \multicolumn{5}{|c|}{ CAPTAN } & \multicolumn{5}{|c|}{ THIRAM } \\
\hline & $K_{f}$ & $\mathbf{n}$ & $\mathbf{R}$ & Kd & Koc & Kf & $\mathbf{n}$ & $\mathbf{R}$ & Kd & Koc \\
\hline $\mathrm{DIG}-0 \%$ & 8.5 & 0.58 & 0.9835 & 0.84 & 26.4 & 12.1 & 0.58 & 0.9857 & 1.32 & 48.2 \\
\hline DIG $-1 \%$ & 10.0 & 0.59 & 0.9982 & 1.09 & 34.3 & 14.3 & 0.60 & 0.9957 & 1.87 & 65.8 \\
\hline DIG $-10 \%$ & 11.0 & 0.60 & 0.9996 & 1.53 & 38.4 & 20.3 & 0.61 & 0.9994 & 2.97 & 66.6 \\
\hline $\mathrm{MAO}-0 \%$ & 4.3 & 0.52 & 0.9969 & 0.27 & 24.8 & 6.93 & 0.47 & 0.9887 & 0.34 & 30.2 \\
\hline MAO - $1 \%$ & 7.5 & 0.53 & 0.9931 & 0.54 & 43.2 & 9.93 & 0.50 & 0.9868 & 0.63 & 50.4 \\
\hline $\mathrm{MAO}-10 \%$ & 10.2 & 0.58 & 0.9923 & 1.15 & 42.4 & 11.6 & 0.59 & 0,9993 & 1.36 & 50.2 \\
\hline HGS $-0 \%$ & 6.1 & 0.57 & 0.9850 & 0.72 & 31.0 & 5.29 & 0.45 & 0.9852 & 0.22 & 9.5 \\
\hline HGS $-1 \%$ & 8.6 & 0.58 & 0.9914 & 0.90 & 36.1 & 8.26 & 0.46 & 0.9954 & 0.41 & 16.5 \\
\hline $\mathrm{HGS}-10 \%$ & 10.6 & 0.58 & 0.9988 & 1.48 & 38.9 & 13.6 & 0.58 & 0.9932 & 1.48 & 39.9 \\
\hline THL $-0 \%$ & 4.9 & 0.53 & 0.9988 & 0.35 & 28.9 & 9.76 & 0.57 & 0.9990 & 0.94 & 77.7 \\
\hline THL - 1\% & 7.8 & 0.54 & 0.9915 & 0.63 & 49.6 & 15.0 & 0.58 & 0.9926 & 1.05 & 82.7 \\
\hline THL $-10 \%$ & 10.5 & 0.60 & 0.9987 & 1.53 & 56.3 & 16.9 & 0.60 & 0.9937 & 2.23 & 82,0 \\
\hline
\end{tabular}

In all cases the values of $\mathrm{n}$ were less than 1.The relationship between the degree of curvature and the value of $\mathrm{n}$ in the Freundlich equation was described by Green and Karickhoff, $(1990)^{26}$, who indicated that the adsorption increases rapidly at low concentrations while slowly approaching a maximum at high concentrations (figure 4).. Kf values ranged between 4.27 (MAO-Captan) to 12.1 (DIG-Thiram) for natural soils; Kf values increased for all soils incubated with 
biosolids, particularly with biosolids at $10 \%$. The highest values were for DIGThiram (20.3) and the lowest for MAO-Captan (10.2). The highest values of $\mathrm{Kf}$ are in accordance with the contents of OC in the soils (Table 1).

Although there are numerous reports about the process of adsorption of pesticides in soils ${ }^{24,27-31}$, there are no studies about the behavior of Captan and only few studies have investigated the behavior of Thiram in natural soils; these found that the adsorption constant $\mathrm{Kd}$ increases with increasing organic carbon content ${ }^{11,32}$

Therefore our results are in agreement with the adsorption of Captan and Thiram, which increased when Koc increased with biosolid matter.

Although the adsorption of pesticides depends strongly upon interaction with organic components in the soils, it is also well known that the interaction with inorganic components of the soils is involved ${ }^{33}, 34$, which depend on the chemical structure of the compounds. In this case the hydrophobocity of Captan (log Kow 2.8) may favor the interaction with organic matter, while there may be less interaction of Thiram with organic matter (log Kow 1.23).

\section{CONCLUSIONS}

The adsorption of pesticides by soils is dominated by interaction with the solid state of the soil. From the results presented here and those of others, the solid state interaction involves both the organic and inorganic fractions, the relative importance of which depended on the relative abundance of these two fractions.

.Captan showed the greatest interaction with natural soils with high organic matter content, while Thiram showed preference for soils with clay high content.

This study showed that incubating soils with biosolids increased the adsorptions of the fungicides Captan and Thiram.

The Freundlich model showed that this process was more efficient when soils were incubated with biosolid at $10 \%$. The highest content of organic carbon from the addition of biosolids to natural soils increased the interaction with both fungicides for all the soils studied; this behavior may help to avoid leaching of the pesticides into groundwater

\section{ACKNOWLEDGMENTS}

The authors want to express their gratefulness to the Chemistry Department and Science Faculty of the Universidad de Chile.

\section{REFERENCES}

1. Epstein, E.; Land Application of Sewage Sludge and Biosolid, Lewis Publishers, CRC Press: Boca Raton, FL, USA, (2003).

2. Moffet, C. A.; Zartman, R. E.; Wester, D. B.; Sosebee, R. E.; J. Environ. Qual., 34, 299 (2005).

3. Acevedo, E. U. Chile SAG pp 33 (2004).

4. Jurado-Guerra, P; Wester, D. B.; Fish, E. B.; J. Environ. Qual, 35, 641 (2006).

5. Ahumada, I., Marican, A., Retamal, M., Pedraza, C., Ascar, L., Carrasco, A., Richter, P., J. Braz. Chem. Soc. 21, 1 (2010).

6. Kabata-Pendias, A.; Pendias, H.; Trace Element in Soils and Plants, $3^{\text {rd }}$ ed., CRC Press: Boca Raton, FL, USA, (2001).

7. McBridge, M. B., J. Environ Qual. 24, 5 (1995)

8. Mantovi, P.; Baldoni, G.; Toderi, G.; Water Res., 39, 289 (2005).

9. Kinney, C. A., Furlong, E. T., Kolpin, D. W., Berkchardr, M- R-, Zaugg, S. D., Werner, S. L., Bossio, J. P.,Benotti, H. M. J., Environ. Sci. Technol. 42, 1863 (2008)

10. Xiangyang, Yu, Ligang Pan, Guangguo Ying, Rai, S. Kookana, Journal of Environmental Sciences. 22, 615 (2010).

11. O. M. S.. Filipe, M. M. Vidal, H. W. Scherer, R. J. Sheneider, A. C. Duarte, V. J. Steves, E. B. H. Santos, Chemosphere 80, 293 (2010).

12. Rodriguez-Liébana, J. A., Mingorance, Ma. D., Peña, A., Journal of environmental Management 92, 650 (2011). .

13. Spark, K. M., R. Swift, R.S. The Science of the total Environment 298, 147 (2002).

14. Majumdar, k., Singh, N., Chemosfere 66, 630 (2007).

15. Chosh, R. K., Singh, N., J. Agric. Food Chem, 57, 632 (2009).

16. El-Aswad, A. F.J. Appl. Sci. Res. 3, 1437 (2007).

17. Dolaptsoglou, C., Karpouzas, D. -c., Menkissoglu-Spiroudi, U., Elftherohorinos I., Voudrias, E. A., J. Environ. Oual. 36, 1793 (2007)

18. Mantovi, P.; Baldoni, G.; Toderi, G.; Water Res. 39, 289, (2005). .

19. Gordon, E.B., Captan and Folpet; Handbook of Pesticide Toxicology:
Volume 2, Agents, Kreiger, R., ED.; 2nd edition, Academic Press, Inc.: San Diego, California, 2001; pp. 1711- 1742.

20. U.S. Department of Agriculture, Soil Conservation Service. 1990 (Nov). SCS/ARS/CES Pesticide Properties Database: Version 2.0 (Summary). USDA - Soil Conservation Service, Syracuse, NY.

21. Clapp, C. E., Stara, S. A., Clay, D. E. And Larson, W. E., E. chen, Y. and Avnimelech (eds). Martines Nijhoff Publishers. Chap. 10, pp 209-253. Day, P.R., Methods of Soil Analysis. Black, C. a. (eds) American Society of Agronomy, Madison, W. I. Part 1. pp 545-566

22. Day, P.R., Methods of Soil Analysis. Black, C. a. (eds) American Society of Agronomy, Madison, W. I. Part 1. pp 545-566

23. Sadzawka, A., Carrasco, M.A.., Grez, R. and Mora, M., Comisión de Normalización y Acreditación Sociedad Chilena de la Ciencias del Suelo. (2004).

24. Beltran, J., Hernandez, F. and Morell, I. Avances en Investigación en Zona No Saturada Ed. J. M. Gonzalo, I. Antiguedad pp: 257-268 (1995).

25. Giles, C., Mac Ewan, T., Nakhwa, S. and Smith, D., J. Chem. Soc. 111, 3973, (1960).

26. Green, R. E., Karickhoff, S. W., SSSA Book series NO 2. Soil Science Society of America, Madison, pp 79-101 (1990).

27. Bermúdez-Couso, A., Fernández-Calvino, D., Pateiro-Moure, M., Novoa-Muñoz, J. C. Simai-Gándara, J., Arias-Estévez, M., Journal of Hazardous Materials, 190, 150 (2011).

28. Bin Liang, Chengli Yang, Mingbo Gong, Yanfu Zhao, Jun Zhang, Changxiong Zhu, Jiandong Jiang, Shunpeng Li, Journal of Environmental Management, 52, 2229 (2011).

29. Arias-Esteves, M., López-Periago, E., Martínez-Carballo, E., SimalGádarsa., J, Mejuto, J.-C., García-Río, L. Agriculture, Ecosystems andEnviroment, 123, 247 (2008).

30. Berlglof, T. Van Dung, T., Kylin, H. Nilsson, I. Chemosfere, 48, 267 (2002).

31. Vischetti, C. Corti, G. Monaci, E. Cocco, S. Coppola, E. Agnelli, A, Geoderma 154, 348 (2010).

32. Filipe, O. M. S., Vidal, M. M., Duarte, a. C., Santos, E. B. h. J. Agric. Food Chem. 57, 4906 (2009).

33. Lima, D. 1. D., Santos, S. M., Sherer, H. W., Schneider, R. J., Duarte, A. C., Santos, E. B. Geoderma, 150, 38 (2009).h., Steves, V. I.,

34. Kovacevic, D. J. Lernic, J., Danjanovic, M., Petronijevic, R., Yancovic D., Stanic, T. Applied Clay Science, 52, 109 (2011). 